\title{
МІЖНАРОДНИЙ ПОРЯДОК ПОЧАТКУ ХХІ СТ.: КРИТЕРІЇ ТА КОНЦЕПЦЇ̈
}

\section{Толстов С. В.}

\section{ВСТУП}

Поняття «міжнародний порядок» вказує на сукупність відносно тривких характеристик міжнародної системи, включно з іiї структурою, співвідношенням сил між основними елементами та наявністю певної нормативної бази. Застосування категорії міжнародного порядку передбачає можливість регулювання міждержавної взаємодії та певної керованості міжнародними процесами. Якщо ж йдеться про «новий», відмінний від попереднього міжнародний порядок, новітні словники вказують, що його основу можуть складати «нова або альтернативна модель соціальної організації, взаємодії чи контролю», «новий баланс сил між країнами, який іноді виявляється в міжнародних домовленостях для збереження політичної стабільності» та/або «стан глобальної політики та глобальної економіки після закінчення холодної війни» .

Найпоширенішим інструментом, покликаним протидіяти стану суцільної анархії, вважається сукупність принципів, які конкретизують загальновизнані чи загальноприйнятні правила зовнішньополітичної поведінки. Оскільки добровільне дотримання загальновизнаних правил і норм становить скоріше виняток, аніж норму, учасники міжнародної системи тяжіють до встановлення певних політичних і моральних рамок - критеріїв, яких різні держави світу мають дотримуватися у своєму спілкуванні з іншими. У цій площині проблема нормативності постає у вигляді пошуку інституціональних механізмів ухвалення та забезпечення колективних рішень, а також форм контролю за дотриманням відповідних процедур та обмежень проти країнпорушників «міжнародного порядку».

Проблематиці міжнародного порядку присвячена велика кількість фундаментальних досліджень і аналітичних розробок. У теоретичному

1 New world order. Lexico (UK dictionary) online. URL: https://www.lexico.com/definition/new_world_order 
відношенні провідна роль належить гегемонічним концепціям міжнародного порядку, побудованим на принципах еволюційного розвитку міжнародних систем. В основу цих концепцій покладено принцип, за яким ознаки міжнародного порядку встановлює держава, спроможна забезпечувати й підтримувати відносний лад у міжнародному середовищі, що досягла гегемонічного статусу в конкурентній боротьбі зі своїми суперниками.

Окремий напрям політичних дискусій становить полеміка довкола перспектив збереження «ліберального міжнародного порядку», який розглядається як специфічна форма міжнародної взаємодії, яка виникла в середовищі ліберальних демократій і набула глобального поширення після закінчення «холодної війни».

Стрімкий характер змін у сучасній системі міжнародних відносин спричинив гостру полеміку щодо змістовних ознак міжнародного порядку XXI ст., в якій постає низка таких проблемних аспектів, як збереження у міжнародних відносинах певних нормативних принципів i правил та спроможність провідних держав світу визначати форми спільного реагування на глобальні проблеми людства. У цьому контексті видається доцільним порівняльний аналіз підходів сучасної політичної думки до проблеми трансформації міжнародного порядку та виявлення принципових перешкод для збереження керованості міжнародних економічних і соціально-політичних процесів.

\section{1. Теоретичні інтерпретації природи міжнародного порядку}

Iз середини XX ст. категорія міжнародного порядку все ширше застосовувалася в дискусіях про характер і стан міжнародної системи та спрямування глобального розвитку. Розпад СРСР та стрімка економічна глобалізація супроводжувалися встановленням гегемонічної моделі, підгрунтя якої визначали незаперечні військовополітичні переваги США, поєднані із системою союзів і закордонною воєнною присутністю, відносною згодою домінуючих гравців 3 колективним забезпеченням глобальної стабільності та поширенням ліберальних правил торгівлі та інвестицій. Наприкінці 1980-х рр., прогнозуючи настання «однополярного моменту» американської гегемонії, американський консервативний політичний оглядач Ч. Краутхаммер відзначав, що така перспектива стала можливою внаслідок унікального збігу обставин на перехідному етапі 
трансформації міжнародної системи ${ }^{2}$. Пізніше Ч. Краутхаммер стверджував, що свідомі зусилля політичних кіл США можуть перетворити «однополярний момент» на тривалу епоху сталого американського панування в однополюсному світі, центром якого буде «конфедеративний» Захід. У цьому сенсі, стверджував Ч. Краутхаммер, «американська мета має передбачати управління світом, аби запобігти його перетворенню на багатополюсний» ${ }^{3}$.

Втім, період безальтернативної гегемонії США виявився надто коротким і доволі нестабільним. Полемізуючи з Ч. Краутхаммером, американський політолог П. Ханна, автор книги «Другий світ» (2008 р.) зазначав, що американо-європейська взаємодія $є$ важливою, хоча й недостатньою передумовою для тривалої гегемонії. За його, як згодом з'ясувалося, надмірно оптимістичним прогнозом, партнерство Америки та Європи 3 таких питань, як торгівля, Афганістан і близькосхідні проблеми заперечувало можливість створення альтернативного «полюса влади» всередині західної цивілізації Водночас П. Ханна зауважував, що сподівання на західну солідарність не мають залишати поза увагою зростання впливу країн «сучасного Сходу». Тому «самий лише Захід не зможе бути єдиним центром влади». Розцінюючи ствердження Ч. Краутхаммера як запізнілі та хибні, П. Ханна підкреслював, що в новітніх умовах «нам потрібні речі, які інтегруватимуть Схід і Захід, а не ті речі, які збурюватимуть Схід підійматися проти Заходу» 5 .

Ретельне обгрунтування природи міжнародного порядку знаходимо в працях американського соціолога І. Валлерстайна. Його концепція пов'язує зміни в міжнародній системі з ії полярністю та наявністю гегемонічної держави. Зв'язок між станом світ-системи та позицією гегемонічного лідера зумовлений тим, що держава-гегемон має забезпечувати стабільній позитивний баланс і бути досить могутньою, аби «нав’язати» відповідний міжнародний порядок. При цьому «цикли гегемонії» мають набагато більшу тяглість, аніж цикли економічної кон'юнктури. Адже у світі, який «складається з множини так званих

${ }^{2}$ Krauthammer C. The Unipolar Moment. Foreign Affairs. Winter 1990/1991. Vol. 70. №. 1. P. 23-33.

3 Krauthammer C. The Unipolar Moment Revisited. The National Interest. Winter 2002/2003. №. 70. P. 5-17.

${ }^{4}$ Khanna P. The Second World. Empires and Influence in the New Global Order. New York : Random House, 2008. 496 p.

${ }^{5}$ Comstock P. Parag Khanna Discusses The Second World. California Literary Review. 2008. March 4th. URL: http://calitreview.com/396 
суверенних держав», ствердитися в ролі держави-гегемона доволі важко. За останні декілька століть це вдавалося лише трьом акторам спочатку Об’єднаним Провінціям (Нідерландам) у середині XVII ст., згодом - Сполученому Королівству (Великій Британії) у середині XIX ст., й нарешті США в середині XX ст. ${ }^{6}$

Піднесення держави-гегемона $\epsilon$ наслідком довгої боротьби 3 іншими потенційними претендентами на гегемонію, однак в усіх відомих випадках роль гегемона діставалася тій державі, якій вдавалося створити найбільш ефективний виробничий механізм, а потім, у більшості випадків - виграти війну з основним суперником. При цьому держава-гегемон має охороняти свій статус та нав'язаний решті світу міжнародний порядок від зазіхань із боку опонентів. На думку І. Валлерстайна, саме ці чинники пояснювали низку війн та військових операцій, які США вели в колишній Югославії, Афганістані, Іраку, Лівії та ін. країнах попри їхній марнотратний характер та невизначеність воєнних цілей. Головна прихована мотивація полягала в тому, аби підтримувати нав'язаний світовий порядок, для чого держава-гегемон має час від часу вдаватися до демонстрації воєнної сили. Водночас нерівномірність розвитку призводить до посилення держав-ревізіоністів, які прагнуть позбавитися диктату держави-гегемона. Якщо ж міць державигегемона вступає у фазу повільного занепаду по відношенню до країнконкурентів, цей процес набуває фактично незворотного характеру, що зумовлює назрівання чергової системної кризи ${ }^{7}$. Заперечуючи суцільну «всемогутність» у межах міждержавної системи, І. Валлерстайн стверджував, що «гегемонія - це скоріше не стан, а один із кінців мінливого континууму, що описує відносини суперництва між великими державами. На одному кінці континууму знаходиться майже точний баланс - ситуація, за якої існує багато держав, певною мірою рівних по силі, без яскраво виражених чи тривалих угруповань. Це рідкісна і нестабільна ситуація. Усередині цього континууму існує багато держав, більш-менш об'єднаних у два табори, а також кілька нейтральних країн чи країн, що коливаються, причому жодна сторона (й тим більше жодна окрема держава) не може нав'язати свою волю

6 Валлерстайн И. Мир, стабильность и легитимность, 1990-2025/2050. Анализ мировых систем и ситуащия в современном мире. Москва : Изд-во «Университетская книга», 2001. С. 347.

7 Валлерстайн И. Динамика глобального кризиса: тридцать лет спустя. Эксперт. 2009. № 35. С. 48-56. 
іншим. На іншому кінці континууму - ситуація гегемонії, також рідкісна і нестабільна» ${ }^{8}$.

Інше змістовне тлумачення міжнародного порядку було запропоновано Г. Кіссінджером, який на початку 1990-х pp., на відміну від багатьох західних політологів, не розглядав глобальне домінування США як сталий системоутворюючий чинник. На думку Г. Кіссінджера, після перемоги в «холодній війні» Америка потрапила у світ, який мав багато спільного із системою європейських держав XVIII і XIX ст. «Відсутність всеосяжної загрози, як ідеологічної, так і стратегічної, дає націям свободу ведення зовнішньої політики, яка все більшою мірою базується на миттєвих національних інтересах. У міжнародній системі, для якої характерна наявність, можливо, п'яти чи шести великих держав i множини менших держав, порядок має виникнути в основному, як і в минулі століття, на базі примирення і балансування між конкуруючими національними інтересами» ${ }^{9}$.

За Г. Кіссінджером, порядок завжди змінюється, якщо змінюють свій характер «складники міжнародної системи». Тому, будучи частково продовженням минулого, а частково - безпрецедентним, новий світовий порядок матиме відповісти на три принципових питання: «Що є фундаментальними складниками світового порядку? Якими є способи їх взаємодії? Якими є цілі, заради яких відбувається така взаємодія?» ${ }^{10}$

Дотримуючись еволюційної логіки, Г. Кіссінджер прогнозував, що остаточні контури нового міжнародного порядку сформуються лише у XXI ст. Й хоча кожний «світовий порядок» втілює потяг до сталості, «елементи, які його складають, знаходяться в безперервному русі». Тому з кожним століттям тривалість існування міжнародних систем зменшується. Порядок після Вестфальського миру протримався півтора століття; міжнародна система, створена Віденським конгресом, прожила сто років; міжнародний порядок, характерний для «холодної війни», знайшов свій кінець через чотири десятиліття. <...> Ніколи ще компоненти світового порядку, їх взаємодія один з одним, завдання, які треба вирішити, не змінювалися настільки швидко й не були настільки глибокі або настільки глобальні» ${ }^{11}$.

${ }^{8}$ Wallerstein I. The Three Instances of Hegemony in the History of the Capitalist World-Economy. International Journal of Comparative Sociology. 1983. Vol. XXIV. № 1-2. Р. 102-103.

${ }^{9}$ Киссинджер Г. Дипломатия. Москва : Ладомир, 1997. С. 733.

${ }^{10}$ Там же. С. 734.

11 Там же. 
Водночас, як можна зрозуміти з аргументації Г. Кіссінджера, жоден порядок не передбачає суцільної стабільності. Адже за відсутності потенційно домінуючої держави інші нації не сприймають загрози миру одноманітно. До того ж «світова спільнота в достатній мірі ладна співпрацювати в справі «підтримання миру», тобто в забезпеченні існуючих угод, які не оспорюються будь-якою зі сторін, але в достатній мірі ухильно ставиться до «забезпечення миру», тобто надання відсічі реальним викликам світовому порядку» ${ }^{12}$. У цьому контексті Г. Кіссінджер відзначав, що після закінчення «холодної війни» політичне керівництво США не мало ясності 3 приводу щодо того, яким зовнішнім викликам слід протидіяти в односторонньому порядку.

У пізніших творах Г. Кіссінджера оцінки міжнародного порядку стали більше нагадувати модель, запропоновану представниками ліберально-інтернаціоналістичної течії американської політології. У своій грунтовній праці «Світовий порядок» (2014 р.) Г. Кіссінджер зауважував, що протягом багатьох років співтовариство націй «існувало в межах «американського консенсусу» - держави співпрацювали, <..> дотримуючись спільних правил i норм, розвиваючи ліберальну економіку, відмовляючись від територіальних завоювань на користь поваги національних суверенітетів і приймаючи представницьку демократичну систему управління». Однак згодом 3'ясувалася відсутність «спільного для всіх уявлення про цю систему», включно зі спільним розумінням «пропорційного внеску» чи «справедливості». Адже за межами західного світу «ті регіони, які брали мінімальну участь у виробленні нинішніх правил, ставлять під сумнів ефективність даних правил в їхніх поточних формулюваннях і ясно демонструють готовність докласти всіх зусиль, аби змінити згадані правила. Таким чином, «міжнародне співтовариство» <... не в змозі узгодити - або хоча б домовитися - про однозначний і несуперечливий комплекс цілей, методів і обмежень» ${ }^{13}$.

Оцінюючи досвід глобального управління в період після «холодної війни», Г. Кіссінджер вказував, що загальні правила системи були проголошені, однак виявилися неефективними за відсутності дієвого примусу до їх виконання. Показовим у цьому сенсі $є$ визнання того, що череда політичних і економічних криз, які виникали внаслідок чи під впливом настанов і дій Заходу, разом із колапсом світопорядку

12 Там же. С. 737.

${ }^{13}$ Киссинджер Г. Мировой порядок. Москва : Изд-во АСТ, 2018. С. 10. 
в окремих регіонах, масовими вбивствами на релігійному грунті, тероризмом і війнами, що завершилися без перемог, - усе це ставить під великий сумнів оптимістичні оцінки про епоху, яка почалася одразу після закінчення холодної війни, насамперед припущення про те, що поширення принципів демократії і вільного ринку автоматично створять справедливий і безпечний світ, спроможний влаштовувати всіх.

Перелічені тези мають принципове значення, враховуючи загальне розбалансування міжнародної системи, руйнування елементів глобального управління, загострення суперництва між провідними центрами сили та потенційну неможливість одноосібної гегемонії якоїсь окремої держави чи групи держав. При цьому дестабілізація однополярної моделі світоустрою позначена не стільки загостренням конкуренції за глобальну гегемонію, скільки запереченням нормативних засад i принципів економічного неолібералізму, який активно нав'язувався країнам світу як супровідний чинник економічної глобалізації.

\section{2. Феномен ліберального міжнародного порядку}

Із середини 1990-х рр. у західній політичній літературі набула популярності концепція ліберального міжнародного порядку. Це поняття з'явилося як метафора, яка вказувала на глобальне розширення правил і стереотипів, запроваджених США та їхніми союзниками в межах євроатлантичної спільноти в період після Другої світової війни. Як відзначав теоретик ліберального інтернаціоналізму Дж. Айкенберрі, Друга світова війна породила два типи повоєнного врегулювання. Перший різновид врегулювання був реакцією на погіршення відносин з Радянським Союзом. Його ознакою був порядок стримування, що базувався на співвідношенні сил, ядерному протистоянні, політичній та ідеологічній конкуренції. Другий тип врегулювання, який відображав реакцію на економічне суперництво, політичні потрясіння 1930-х рр. І світову війну як їхню похідну, можна назвати ліберально-демократичним порядком. Він знайшов утілення в широкому спектрі нових інститутів та відносин між західними індустріальними демократіями, побудованими на основі економічної відкритості, політичної взаємності та багатостороннього управління ліберальною політичною системою під керівництвом США ${ }^{14}$.

${ }^{14}$ Ikenberry G.J. The Myth of Post-Cold War Chaos. Foreign Affairs. May/June 1996. Vol. 75. №. 3. P. 79-91. 
Дж. Айкенберрі доводив, що практика ліберальних держав щодо спільного управління торгівлею, безпекою та іншими важливими питаннями набула ознак глибоко вкоріненої традиції, підкріпленої «американським досвідом демократії та конституціоналізму», а результати позитивних перетворень у Німеччині та Японії слугували привабливим прикладом для решти світу. Тому, посилаючись на збереження єдності в межах спільноти ліберальних демократій, Дж. Айкенберрі переконував, що після закінчення «холодної війни» міжнародна структура, створена країнами євроатлантичного співтовариства в 1940-х pp., може становити основу глобального міжнародного порядку, а завдання американської зовнішньої політики полягає не в тому, аби побудувати новий світовий порядок, а в тому, аби відродити і відновити старий міцний та інноваційний лад, який упродовж тривалого часу демонстрував надзвичайну успішність.

Для країн євроатлантичної спільноти та низки позаєвропейських демократій цінність ліберального порядку періоду 1990-2008 pр. визначалася здобутками тривалого миру, відносної економічної стабільності та зростання рівня життя більшості населення. Альтернатива ліберальному порядку постає у формі загострення конфронтації між провідними великими державами, що взагалі перекреслює сподівання на розв'язання глобальних проблем людства. Натомість загострення конкуренції та суперництва становлять виклик усім трьом опорам стабільного і відносно гармонійного глобального розвитку, таким як раціональний підхід до регулювання міжнародних відносин, наявність прийнятних нормативних правил та відкритість економік і політичних систем.

У політичних колах дискусія про перспективи ліберального міжнародного порядку розпочалася ще в першій половині 2010-х рр. В ii перебігу визначилися дві основні точки зору. Перша полягає в неминучості збереження суттєвих ознак та важелів керованості в межах міжнародної системи, оскільки це відповідає інтересам переважної більшості держав світу. Зміст другого концепту полягає в неминучості трансформації міжнародного порядку під тиском загострення суперництва між провідними центрами сили. Адептами умовного «оптимістичного» підходу виступають такі відомі автори, як Дж. Айкенберрі ${ }^{15}, \quad$ I. Даалдер ${ }^{16}, \quad$ М. Леонард ${ }^{17}, \quad$ Дж. Най ${ }^{18}$.

${ }^{15}$ Ikenberry G.J. The end of liberal international order? International Affairs. 2018. Vol. 94. №. 1. P. 7-23 ; Ikenberry G.J. Why the Liberal World Order Will Survive. Ethics and International Affairs. 2018. Vol. 32. № 1. P. 17-29. 
Обгрунтування скептично-раціоналістського підходу знаходимо в працях А. Ачарії ${ }^{19}$, Г. Еллісона ${ }^{20}$, Р. Хаaса ${ }^{21}$ та інших авторів, які вважають неминучою суттєву корекцію міжнародного порядку відповідно до нової розстановки сил, яка своєю чергою визначає нові тенденції та способи міждержавної взаємодії.

Окрема концепція, викладена Дж. Міршаймером ${ }^{22}$, пропонує розглядати напрями трансформації міжнародного порядку насамперед як наслідок структурних змін у міжнародній системі, які визначатимуть перебіг міжнародних процесів крізь призму відносин між провідними центрами сили. При цьому базовий сценарій у прогнозі Дж. Міршаймера передбачає виокремлення в межах загального, рамкового міжнародного порядку автономних зон з відмінними нормативними режимами.

У сучасній міжнародно-політичній дискусії довкола перспектив ліберального міжнародного порядку глобальна фінансово-економічна криза 2008-2009 рр. відіграє роль межі, яка відділяє еру «гегемонічної стабільності» від вочевидь нестаціонарної й нерівноважної міжнародної системи, позначеної посиленням напруженості та небезпечним загостренням конфронтаційних тенденцій. Криза 20082009 рр. сприяла прояву нових загроз міжнародній стабільності, а іiі наслідки власне й спричинили суперечку про перспективи збереження ліберального міжнародного порядку, побудованого на домінуванні США та їхніх союзників як умовної спільноти держав «колективного Заходу».

Серед різноманітних коментарів із приводу природи ліберального міжнародного порядку суттєво вирізняється модель, запропонована

16 Daalder I.H., Lindsay J.M. The Committee to Save the World Order. America's Allies Must Step Up as America Steps Down. Foreign Affairs. November/December 2018. Vol. 97. № 6. P. 72-83.

${ }^{17}$ Leonard M. What Liberal World Order? The Strategist. 2017. March 3. URL: https://www.aspistrategist.org.au/what-liberal-world-order/

${ }^{18}$ Nye J.S. Will the Liberal Order Survive? The History of an Idea. Foreign Affairs. January/February 2017. Vol. 96. № 1. P. 10-16.

${ }^{19}$ Acharya A. After Liberal Hegemony: The Advent of a Multiplex World Order. Ethics \& International Affairs. Fall 2017. Vol. 31. № 3. P. 271-285.

${ }^{20}$ Allison G. The Myth of the Liberal Order: From Historical Accident to Conventional Wisdom. Foreign Affairs. July/August 2018. Vol. 97. № 4. P. 124-133.

${ }^{21}$ Haass R. How a World Order Ends: And What It Comes in Its Wake? Foreign Affairs. January/February 2019. Vol. 98. № 1. P. 22-30.

${ }^{22}$ Mearsheimer J.J. Bound to Fail. The Rise and Fall of the Liberal International Order. International Security. Spring 2019. Vol. 43. № 4. P. 7-50. 
головою американської Ради 3 міжнародних відносин Р. Хаасом. Відкидаючи твердження про ліберальний порядок як ледь не уособлення ідеалістичних уявлень про справедливий міжнародний устрій, Р. Хаас доводить, що глобальний порядок, побудований після Другої світової війни, «складався 3 «двох паралельних порядків» порядку стримування, побудованому на балансі сил між США та СРСР, та ліберального порядку, встановленого між країнами євроатлантичного співтовариства. Р. Хаас відзначає, що у своєму суперництві США та СРСР демонстрували певну стриманість і відкидали ідеї «відкату назад» (тогочасне поняття, що слугувало аналогом сучасної практики «зміни режимів») як нереалізуєму й безрозсудну. США та СРСР дотримувалися «неофіційних правил гри», включаючи повагу до сфер впливу та статусу союзників. Кінець кінцем вони прийшли до узгодженого розуміння політичного порядку на основній арені «холодної війни» в Європі й у 1975 р. закріпили це порозуміння в Хельсінкському Заключному акті НБСС. Два центри сили змогли домовитися про те, як буде відбуватися суперництво. Тому «цей порядок базувався на засобах, а не на цілях. А наявність лише двох центрів сили полегшила досягнення угоди» ${ }^{23}$.

Натомість міжнародний порядок у відносинах між демократіями був насправді ліберальним. Вільна торгівля набула ознак драйвера економічного зростання, тому розпочинати війну стало надто дорогим задоволенням. Принципове значення мало й те, що глобальний порядок, попри формальне визнання верховенства ООН, залежав від готовності некомуністичного світу, насамперед союзників США, визнавати американську гегемонію. Отже, у підсумку обидва порядки служили інтересам США.

Важливим, якщо не головним елементом у концепції ліберального міжнародного порядку є теза про те, що саморозпуск СРСР і розпад радянської системи впливів призвели до універсального розширення режиму відносин, який встановився між демократичними державами західного світу. При цьому головна політична тенденція подавалася як всесвітній транзит від авторитаризму до демократії та ринкової економіки, а головне протиріччя нової епохи після демонтажу більшості комуністичних режимів подавалося як протистояння між спільнотою демократичних держав та авторитарними й диктаторськими режимами, які уособлювали архаїчні форми політичного устрою. Окремі відступи від ліберальних принципів у міждержавних

${ }^{23}$ Haass R. Вказ. праця. Р. 26. 
відносинах мотивувалися необхідністю силового реагування на дії авторитарних режимів, які застосовували практику масового порушення прав людини, розхитували нерозповсюдження зброї масового враження чи уособлювали небезпеку для сусідніх країн. Як форми реагування на ці загрози мали застосовуватися несилові засоби тиску (санкції) та силові методи (застосування стандартних форм реагування на кризи на кшталт операцій із силового примусу до миру чи проведення гуманітарних інтервенцій). При цьому враховувалася неминучість певних, й подекуди суттєвих відступів від ліберальних принципів міжнародного спілкування, а головним пріоритетом, якого мали дотримуватися військові контингенти США, союзників та країнучасниць багатонаціональних коаліцій в Афганістані, Іраку, Сирії чи Лівії, була безпека особового складу експедиційних військ.

Застосування різних стандартів у тлумаченні конфліктних ситуацій i способів реагування на них у державах західного системного ядра та в країнах периферії навряд чи виглядало дивним. Адже й під час існування біполярної системи дотримання мирного співіснування і діалогу у відносинах між США та СРСР не заперечувало непряме суперництво із застосуванням сили i підтримку протилежних ворогуючих сторін у країнах «третього світу».

Під впливом глобальної фінансово-економічної кризи 2008-2009 pp. у західних політичних колах з'явилося усвідомлення, що глобалізація виявилася нетотожною вестернізації. Адже наслідки глобалізації багато в чому відрізнялися від початкових очікувань, пов'язаних зі зміцненням економіко-технологічного домінування Заходу та послідовного впливу країн Заходу на трансформацію політичних систем та економік у незахідному світі. Глобалізація не запобігла появі нових центрів економічного зростання, ефективність яких виявилася іншою, хоча й подекуди не меншою, ніж у традиційних фінансових і промислових осередках світової капіталістичної системи.

Для західної спільноти джерелом тривоги стала низка небезпечних симптомів, таких як боргова криза, зростання бюджетних дефіцитів, загострення інституціональних дисбалансів та політичних протиріч у країнах СС, ревізіонізм у політиці Росії та Китаю і поширення авторитарних тенденцій у численних країнах - від Угорщини до Венесуели. Утім, найбільш потужним викликом «ліберальному» міжнародному порядку стала перемога Д. Трампа та його політика на посаді президента США у 2017-2020 pp.

Попри зростання ролі незахідних центрів сили, міжнародна стратегія США залишається ключовим чинником, який впливає на 
спрямування тенденцій глобального розвитку. Отже, критичну загрозу послаблення, а можливо й руйнування ліберального міжнародного режиму, побудованого на західних правилах гри, становить саме відмова адміністрації США від традиційного курсу у сфері міжнародної безпеки. 3 цього погляду питання про те, чи залишатимуться США гарантом стабільності у відносинах між провідними державами, чималою мірою залежить від того, яку позицію офіційний Вашингтон займатиме у відносинах iз традиційними союзниками США. Закидаючи традиційним партнерам використання нечесних методів конкуренції, Д. Трамп поставив за мету радикальний перегляд торговельних угод, що мало сприяти відновленню виробничого потенціалу американської економіки. Утім, курс «безкомпромісного реалізму» його адміністрації не можна ототожнювати 3 ізоляціонізмом. Із цього приводу директор програми досліджень у галузі безпеки в Массачузетському технологічному інституті професор Б. Позен справедливо відзначав, що позиціонування Д. Трампа в міжнародних відносинах залишалося послідовно гегемоністським i радше відповідає ознакам «неліберальної гегемонії» ${ }^{24}$. На відміну від політики більшості попередніх президентів США, які дотримувалися звичних формальностей і показної доброзичливості у відносинах із провідними, насамперед європейськими союзниками, зовнішньополітичний курс Д. Трампа грунтується на запереченні ментальних основ західної солідарності.

Своєю чергою поширення технологій і нерівномірність розвитку сприяли піднесенню Росії та Китаю, на які значною мірою орієнтувалися інші супротивники США, включно з Іраном і Північною Кореєю. На думку віце-президента Центру стратегічних і міжнародних досліджень Дж. Льюїса, «мотиви, що спонукають Росію та Китай, є оборонними та реваншистськими». Обидві держави хочуть «повернути собі те, що вони вважають своїм законним місцем у світових справах, але вразливість їхніх режимів і занепокоєння, що США будуть використовувати ці вади, є основним джерелом їхньої опозиції». 3 їхньої точки зору США прагнуть впливати і втручатися за згодою чи без згоди ООН - аби переладнати за своїми потребами інші країни та народи. Тому спротив опонентів американоцентричному міжнародному порядку чи спроби створення альтернатив західній «інформаційній гегемонії» мотивуються протистоянням тому, що

${ }^{24}$ Posen B.R. The Rise of Illiberal Hegemony: Trump's Surprising Grand Strategy. Foreign Affairs. March/April 2018. Vol. 97. № 2. P. 20-27. 
політична еліта цих країн вважає за всебічну американську стратегію домінування. Іран і Північна Корея поділяють ці думки, і всі чотири країни разом прагнуть «використовувати нетрадиційні засоби для нанесення шкоди США. Наразі побоювання, що вони є кінцевими цілями політики зміни режимів, дещо пом'якшені успіхом їхніх зусиль, спрямованих проти США» ${ }^{25}$.

Висловлюючи ці застереження, Дж. Льюїс попереджав, що світ вступив у «конфліктний період», який не обов'язково веде до прямого військового конфлікту чи нової «холодної війни», адже економічна взаємопов'язаність гальмує надто різкі розриви між державамисуперниками. Проте навіть якщо за умови військово-технологічної переваги США конфлікт стосуватиметься переважно політичних та інформаційних аспектів, це потенційно не виключає застосування сили. Хоча опоненти США «воліли б уникати використання звичайних збройних сил для досягнення своїх цілей, ризик збройних конфліктів значно зростає». Причина в тому, що опонентів США «спокушає відчуття американської слабкості, що провокує їх до спроб примусового перерозподілу світу, <..> зокрема в Сирії, Криму, Південнокитайському морі й, можливо, в інших місцях» ${ }^{26}$.

Серед причин кризи ліберального світового порядку сучасні американські дослідники вказують на низку істотних прорахунків у політиці США після 2000 р., включно 3 інтервенцією до Іраку. Помилкові рішення завдавали шкоди США та створеним ними союзам i дискредитували концепцію поширення демократії. Окрім цього, вдаються взнаки й очевидні внутрішні обставини, які зумовили специфіку виборчої кампанії 2016 р. та перемогу кандидата з чіткими націоналістичними гаслами. Виборча кампанія Д. Трампа досягла успіху тому, що була спрямована проти глобалістично налаштованої еліти, байдужої до інтересів кваліфікованих робітників і переважної частини середнього класу. Тому, як стверджує професор Прінстонського університету Дж. Айкенберрі, президент Трамп $€$ водночас і наслідком, і причиною теперішньої кризи. Його прихід на посаду - очевидний «крок у бік підриву ролі США як провідної країни міжнародного порядку». Утім, на думку Дж. Айкенберрі, «ліберальна демократія, враховуючи іiі здатність до вдосконалення і саморегуляції, все ж зберігає подальшу перспективу». До того ж «життєздатна

25 Lewis J.A. What role should values play in American strategy? Global Forecast 2017. Washington : CSIS, 2016. P. 95.

26 Там же. 
альтернатива ліберальному міжнародному порядку», який забезпечує «природну спадковість» у міжнародних відносинах, наразі відсутня, а численні національні держави так чи інакше поставатимуть перед потребами у розв'язанні великих і взаємопов'язаних проблем, з якими вони не здатні впоратися самотужки ${ }^{27}$.

Дж. Айкенберрі звертав увагу на нагальну потребу виправлення помилок, котрі призвели до кризи ліберального проекту, який раніше мав підтримку населення в просуванні глобального капіталізму, однак згодом втратив «свій соціал-демократичний зміст». Отже, вдосконалення міжнародного порядку можливе за умови, якщо він буде зберігати систему стримувань і противаг, включно з гарантіями на користь меншин, дотриманням свободи слова, свободи ЗМІ, свободи віросповідання тощо. Інша вагома обставина стосується побудови «рівномірного міжнародного порядку», здатного забезпечувати вигідні умови для всіх ліберальних демократій та відновити «довіру до інтернаціоналізму».

Сподівання Дж. Айкенберрі на відновлення життєздатності лібералізму зумовлені тим, що демократії з відносно високим рівнем середнього доходу рідко скочуються до авторитаризму чи особистої влади (якщо не брати до уваги такі винятки, як Туреччину). Водночас Дж. Айкенберрі змушений визнати, що наука й досі не дала чіткої відповіді на питання, чому окремі країни перетворюються на демократичні, а інші залишаються авторитарними. Що стосується Заходу, вірним рішенням має бути подолання розриву в доходах $\mathrm{i}$ припинення стагнації середнього класу, які підривають довіру народу до правлячих еліт і ЗМІ, спричиняють занепад політичних партій та девальвацію демократичних цінностей. Своєю чергою зміцнення західних суспільств має упередити «перехід глобальної влади» до «нових держав», що перебувають у фазі піднесення, та не дозволити вийти з-під контролю надзвичайно складним питанням взаємозалежності включно з розповсюдженням ядерної зброї, регулюванням фінансової системи, міграціями, упередженням пандемій тощо ${ }^{28}$.

Полемізуючи 3 прибічниками ліберального інтернаціоналізму, голова американської Ради з міжнародних відносин Р. Хаас висловив

${ }^{27}$ It's not just Trump. Challenges to the liberal international order, according to John Ikenberry. Luiss School of Government. May 25, 2017. URL: http://open.luiss.it/en/2017/05/25/non-solo-trump-le-sfide-allordine-internazionaleliberale-secondo-ikenberry/

${ }^{28}$ Ikenberry G.J. The end of liberal international order? International Affairs. 2018. Vol. 94. № 1. P. 7-23. 
низку слушних аргументів, які відображають критичне ставлення до перспектив збереження ліберального міжнародного порядку в його звичних рисах:

1. Руйнування міжнародного порядку почалося майже одразу після закінчення «холодної війни» у формі скасування елементів взаємного стримування між центрами влади біполярної системи. По закінченні «холодної війни» тогочасний глобальний порядок руйнувався поступово й «по частинах» - імовірно, через невдачу спроб Заходу інтегрувати Росію до спільноти демократій та відповідних інституцій. Однією з перших ознак руйнування старого порядку стало вторгнення Саддама Хусейна до Кувейту 1990 р. За часів максимальної могутності СРСР Москва, напевно, запобігла б цій авантюрі як занадто ризикованій, однак не змогла упередити іiї в 1990 р.

2. Розширення НАТО, політика «зміни режимів» та воєнні інтервенції в Іраку (2003р.) та Лівії (2011р.) суперечили базовим принципам старого, Ялтинсько-Потсдамського світового порядку й засвідчили ігнорування основних інструментів взаємного стримування. Й хоча «Росія не кидала прямих воєнних викликів НАТО», вона, тим не менше, демонструвала готовність порушувати статус-кво, у тому числі шляхом застосування сили в Грузії (2008 р.), Україні (3 2014 р.), інтервенції в Сирії, а також агресивного використання кіберпростору з метою впливу на результати виборів у США та країнах Європи.

3. Фактор ядерного стримування ще діє, але більшість угод 3 контролю над озброєннями зруйновані чи перебувають у стадії деградації.

4. Авторитарна реставрація теж має розглядатися як пряма ознака розхитування ліберального порядку, про що свідчать зміни в політичних системах не тільки Росії та КНР, але й відповідні тенденції на Філіппінах, у Туреччині та в Східній Європі.

5. Хоча глобальна торгівля зросла, останні раунди торговельних переговорів завершилися марно. СОТ, вочевидь, неспроможна розв'язати ключові виклики сьогодення, такі як нетарифні бар'єри та гарантування інтелектуальної власності.

6. Зміни в розстановці сил між провідними центрами сили блокують механізми глобального управління. Рада Безпеки $\mathrm{OOH}$ демонструє нездатність розв'язати більшість світових конфліктів, iï склад не відображає реальне співвідношення сил, а система міжнародних угод демонструє неефективність перед викликами глобалізації. 
7. Окрему проблему становить стрімке зростання державного боргу США та використання долара під час застосування санкцій.

8. Політика США безпосередньо впливала на дезорганізацію міжнародного порядку. Адже спочатку США переоцінили свої можливості щодо перебудови «Великого Близького Сходу», вдавшись до воєнної окупації Афганістану, Іраку та зміни режиму в Лівії, а згодом відмовилися від жорсткого реагування на перше застосування хімічної зброї в Сирії. Така поведінка підбурювала інші країни до самостійних дій, таких як інтервенція Саудівської Аравії в Ємені чи втручання Росії в Сирії та Україні. Так само й «вихід адміністрації Д. Трампа з низки міжнародних угод та висунення умов у межах колись непорушних альянсів у Європі та Азії» створює сумніви в надійності США як світового лідера.

\section{3. Прогноз Дж. Міршаймера}

Попри численні спекуляції $з$ приводу можливості відновлення чи реформування ліберального міжнародного порядку, в середовищі західних політологів поширюється усвідомлення, що до попереднього режиму глобального управління світ уже напевно не повернеться. У своїй статті про піднесення й занепад ліберального міжнародного порядку представник неореалістичного напряму Дж. Міршаймер окреслив декілька напрямів, по яких трансформуватиметься міжнародний порядок в умовах становлення багатополярної міжнародної системи. Погоджуючись із тим, що основним критерієм світового порядку $\epsilon$ «глобальний розподіл сил», Дж. Міршаймер висловив гіпотезу, про можливість співіснування, як і за часів «холодної війни», різних форм міжнародного порядку. Відмінність між різними формами міжнародного порядку полягає в широті охоплення. Так, за логікою Дж. Міршаймера, міжнародний порядок може бути рамковим або загальним, чи навпаки, обмеженим та регіональним ${ }^{29}$.

Для того аби міжнародний порядок розглядався як загальний, він має включати в себе всі великі держави світу. «Обмежені» порядки мають вужче охоплення й призначені головним чином для того, аби конкуруючі великі держави могли вести конкурентну боротьбу одна 3 одною. Так само різні форми міжнародних порядків можуть характеризуватися як реалістичні, агностичні чи ідеологічні (включаючи його ліберальний різновид). Форма чи тип міжнародного порядку залежить насамперед від розподілу сил між великими

${ }^{29}$ Mearsheimer J.J. Вказ. праця. Р. 40-42. 
державами. При цьому ключовим чинником є полярність міжнародної системи.

Ці твердження Дж. Міршаймер ілюструє прикладами з недавньої історії. Так, після Другої світової війни система зазнала трансформації та перейшла від багатополярного до біполярного світового порядку (1945-1989 рр.). Як основні протагоністи післявоєнного світу США і СРСР сформували «всеосяжний міжнародний порядок» (overarching international order), який не був ні ліберальним, ні комуністичним, однак повністю відповідав інтересам безпеки обох сторін. Після розпаду СРСР адміністрація США, починаючи 3 президентства Дж. Буша-старшого, розпочала процес розширення ліберального міжнародного порядку на решту світу ${ }^{30}$. При цьому встановлення ліберального міжнародного порядку передбачало вирішення трьох основних завдань:

- розширення впливу адептів ліберального порядку в міжнародних інститутах;

- створення відкритої та інклюзивної міжнародної економіки на засадах вільної торгівлі та лібералізації ринків капіталу;

- експорту ліберальної демократії по всьому світу.

Цим завданням відповідало залучення трьох основних ліберальних теорій - ліберального інституціоналізму, економічної взаємозалежності й демократичного миру. Зазначена теоретична концепція передбачала демократичний транзит Китаю та Росії, їхню інтеграцію до відкритої економічної системи та якомога більшу кількість сформованих державами Заходу міжнародних інститутів.

Дж. Міршаймер стверджує, що розширення НАТО на схід не було частиною класичної стратегії стримування Росії. Адже мета полягала в тому, аби інтегрувати країни Східної Свропи i, по можливості, Росію до ліберального «співтовариства безпеки», яке сформувалося в Західній Європі під час «холодної війни». Так само й політика щодо Китаю полягала в його демократизації та інтегруванні в економічний порядок під егідою США.

На думку Дж. Міршаймера, криза ліберального міжнародного порядку була багато в чому спричинена наслідками глобальної фінансово-економічної кризи, хибними розрахунками доктрини Дж. Буша-молодшого i помилковими рішеннями адміністрації Б. Обами. У 1991-2004 рр. політика США здебільшого грунтувалася на ліберальних теоріях, які заперечували логіку політичного реалізму.

${ }^{30}$ Там же. Р. 20-28. 
Натомість переважна більшість реалістів виступала проти розширення НАТО, війни в Іраку, експорту демократії в країни Близького та Середнього Сходу та ігнорування балансу сил. Й лише переглянувши попередні постулати, адміністрація Д. Трампа почала повертатися до політики стримування по відношенню до Китаю і Росії. Проте навіть у період сталої однополярної гегемонії США навряд чи змогли б у повній мірі використати свій потенціал для побудови більш справедливого й гармонічного глобального режиму. Причину цього Дж. Міршаймер бачить у трьох «родових вадах» ліберального міжнародного порядку. Серед них:

- неможливість реалізації амбітного проекту соціальної інженерії в глобальному масштабі;

- недооцінка прагнення народів ряду країн до збереження національної ідентичності та суверенітету;

- економічні та соціальні наслідки «гіперглобалізації», яка позначилася на погіршенні становища значних прошарків населення всередині самих ліберальних демократій.

Пояснюючи ці тези, Дж. Міршаймер відзначає, що спроби США збройним шляхом просувати демократію призвели до череди фактично програних війн. Експорт демократії та зміна режимів спричинили пожвавлення націоналізму. Своєю чергою зміни в балансі сил стимулювали об'єднання супротивників гегемонії США та посилення різнопланового спротиву 3 їх боку, що сприяло розхитуванню однополярності й, відповідно, обмежувало ефективність ліберального міжнародного порядку. Отже, як попереджає Дж. Міршаймер, у зв'язку із завершенням однополярного періоду в найближчому майбутньому немає жодних шансів для відродження будь-якої форми ліберального міжнародного порядку. У новому багатополярному світі, ймовірно, домінуватимуть різні типи реалістичних порядків, позначені подальшим погіршенням відносин між Росією та Заходом і загостренням суперництва між США та Китаєм. За президентства Д. Трампа поглибилися тріщини і в трансатлантичних відносинах. При цьому Д. Трамп з недовірою ставиться практично до всіх інститутів, що уособлюють ліберальний міжнародний порядок, у т. ч. до ЄС і НАТО. 3 другого боку, схвально ставлячись до зростання Китаю, західні політики фактично допомогли підірвати ліберальний порядок, оскільки Китай швидко перетворився на економічну державу зі значними військовими можливостями. Зі зростанням Китаю та поверненням Росії міжнародна система стала багатополярною, що є головним згубним фактором для ліберального міжнародного 
порядку. Китай і Росія чинять опір засадам ліберального порядку з реалістичних причин, оскільки його втілення дозволило б США домінувати в міжнародній системі в економічному, військовому і політичному відношенні. Тому, як вважає Дж. Міршаймер, з обранням Д. Трампа на посаду президента США ліберальний світовий порядок перетворився б на агностичний, навіть якби міжнародна система залишалася однополярною.

Описана Дж. Міршаймером модель включає три форми міжнародних порядків «реалістичного» типу:

1) Міжнародний порядок на глобальному рівні оцінюється як «слабкий» та рамковий (thin overarching international order). Його компетенція поширюватиметься головно на контроль над озброєннями, забезпечення регулятивних норм світової економіки та проблематику зміни клімату. Інститути, що уособлюватимуть цю форму міжнародного порядку, будуть зосереджені на сприянні міждержавному співробітництву. Побічно це нагадує вже існуючий формат багатосторонніх консультацій G20, який обговорює весь комплекс політико-економічних питань та уникає юридично зобов'язуючих рішень.

2) Паралельно із цим рамковим форматом існуватимуть два типи жорстко обмежених (thick bounded) міжнародних порядків: один на чолі з Китаєм та інший - на чолі зі США. Вони будуть зосереджені насамперед на конкуренції у сфері безпеки. Висловлюється теза, що жорстка економічна політика адміністрації Д. Трампа щодо Китаю - це тільки початок того, що обіцяе стати тривалим та інтенсивним суперництвом між «жорстко обмеженими» порядками США і Китаю 3 тенденцією до посилення взаємного антагонізму між ними ${ }^{31}$.

Загалом, викладений прогноз вражає схожістю нової архітектури зі світоустроєм біполярного світу часів «холодної війни». Окрім високого ступеня глобальної економічної взаємозалежності, основні відмінності полягають у частковій зміні лідерів та більш автономній ролі інших важливих суб’єктів міжнародної політики, включно з ЄС, Росією, Японією, Індією та низкою акторів середнього рівня.

Доцільно зауважити, що розглянута модель, вочевидь, недооцінює інерційні тенденції світової політики та ступінь зацікавленості інших країн у збереженні передбачуваності міжнародної взаємодії. Як стверджують прибічники реформістського підходу, збереження окремих ознак та механізмів ліберального міжнародного порядку

${ }^{31}$ Там же. Р. 15-16, 44-49. 
відповідає намірам політичних кіл більшості держав ЄС та впливових регіональних країн у незахідному світі. 3 цього погляду перспектива жорсткого блокового розколу світу, який описує модель Дж. Міршаймера, виглядає надто песимістичною.

На думку російського дослідника А. Кортунова, перспективи ліберального міжнародного порядку доцільно розглядати з точки зору міцності та популярності його базових принципів - раціональності, нормативності та відкритості. При цьому А. Кортунов робить цілком слушні припущення, що ліберальний міжнародний порядок не варто ототожнювати 3 американською гегемонією попри безперечний взаємозв'язок між цими явищами, а також що ліберальний світовий порядок виявився загалом ширшим і привабливішим, аніж політична ідеологія лібералізму чи неолібералізму в іï теперішньому вигляді ${ }^{32}$. Виходячи 3 оцінки перспектив життєздатності трьох базових принципів ліберального міжнародного порядку, А. Кортунов припускає, що більшість країн поділятимуть зацікавленість у збереженні принципів ліберального раціоналізму та значного ступеня взаємної відкритості, попри очевидне посилення тенденції до регіоналізації в регулюванні режимів торгівлі та економічних відносин. Тому навряд чи уряди багатьох країн, включаючи союзників США, беззастережно наслідуватимуть дії США, спрямовані на ізоляцію Китаю. Так само й Китай скоріше уникатиме конфронтації зі США, ніж вдаватиметься до демонстрації сили.

3 приводу критерію нормативності зміст проблеми виглядає дещо складнішим. Єдині для всіх норми i стандарти поведінки $\epsilon$ стереотипним ідеалом ліберального міжнародного порядку. Такі норми можуть бути обов'язковими чи добровільними, закріпленими в договорах чи заснованими на прецедентах. Вони можуть здійснюватися через міжнародні організації, багатосторонні режими чи безпосередньо у відносинах між окремими країнами. Проте ці норми мають бути спільними для всіх. Умовну альтернативу нормативній єдності становлять всілякі варіанти світового безладу та хронічної нестабільності. Тому очевидну альтернативу ліберальному порядку становить «повернення до світу жорстко сконструйованих ієрархічних імперій, закритих регіональних торговельних альянсів і військовополітичних блоків» ${ }^{33}$.

${ }^{32}$ Кортунов А. Неизбежность странного мира. РCMД. 15 июля 2016 г. URL: http://old.russiancouncil.ru/inner/?id_4=7930\#top-content

33 Там же. 
У разі загострення суперництва між провідними державами не можна відкидати й можливих спроб нав'язати впровадження різних, відмінних за змістом систем правил усередині окремих блоків. Такі спроби не важко помітити в практиці деяких об'єднань інтеграційного типу. Однак дотепер поряд із ними застосовувалися більш гнучкі загальні правила, що дозволяло підтримувати торговельні, інформаційні та інвестиційні відносини між різними державами та регіонами.

\section{ВИСНОВКИ}

Загалом, попри періодичне порушення норм міжнародного права за останні 20-30 років система міжнародно-правового регулювання стала значно більш безпечною та ефективною. Хоча прогресуюче зменшення керованості світової системи вважається характерним проявом кризи міжнародного порядку, не можна не помітити й певних позитивних ознак, пов'язаних з розширенням кола й кількості учасників діалогу з глобальних проблем. Впродовж 2010-х рр. формат G20 перебрав на себе функції основної платформи глобального економічного діалогу, хоча загальні принципи роботи групи залишилися такими ж, як і в $\mathrm{G} 7 / \mathrm{G} 8$.

Підводячи підсумок, доцільно відзначити, що полеміка довкола перспектив збереження ліберального міжнародного порядку не має сенсу у відриві від прогнозування тенденцій та оцінки структурної будови міжнародної системи XXI ст. У новій багатополярній міжнародній системі багато що залежатиме не тільки від балансу сил між основними опонентами й суперниками, а й від ступеня іï децентралізації. Якщо в гегемонічній міжнародній системі міжнародний порядок гарантує інтереси домінуючої держави та забезпечує стабільність ії панівного статусу, то в децентралізованій, а отже, у нерівноважній системі відкритого типу головна функція світового порядку, сформульована в термінах ліберальної ідеалістичної раціональності, має становити максимальне використання можливостей багатосторонньої взаємодії та управління наслідками глобалізації. Ця функція має охоплювати розподіл вигід, регулювання поширення технологій, узгоджене розширення нових форм співпраці та мінімізацію ризиків і втрат.

Нездатність США виконувати гегемоністську роль у традиційному, повному обсязі, включно 3 відсутністю важелів, спроможних контролювати міжнародну політику Росії та КНР, може призвести до деградації чи навіть блокування діяльності існуючих міжнародних 
інституцій. Особливо це стосується можливих епізодів прямого й критичного загострення відносин між США з РФ і Китаєм як з головними опонентами. При цьому, враховуючи спектр протиріч, наявність численних локальних конфліктів i територіальних зон суперництва, приводи для загострення відносин можуть спорадично виникати в багатьох регіонах світу.

В умовах нової багатополярності велику роль відіграватиме політика ряду впливових країн, які можуть виступити на захист принципів ліберального порядку в межах неформальних коаліцій. Серед таких імовірних груп по інтересах окремі експерти вже розглядали перспективи створення групи G9 (у складі СС, Франції, ФРН, Італії, Великої Британії, Австралії, Японії, Південної Кореї та Канади) та CANZUK (у складі Канади, Австралії, Нової Зеландії та Великої Британії). У сукупності 3 деякими провідними неєвропейськими країнами блок прибічників реформованого світового порядку, побудованого на загальноприйнятних правилах, міг би створити суттєву противагу великодержавній конфронтації. Утім, для цього потрібно, аби правила міжнародного порядку більш гармонійно враховували інтереси незахідних країн та передбачали певні інструменти стримування, здані запобігати порушенню правил як 3 боку США, так і з боку РФ, КНР чи інших країн.

Важливий напрям подальших досліджень має охоплювати спостереження тенденцій, що формуються, та аналіз форм, змісту і стилю сучасних міждержавних відносин. У цьому сенсі можна констатувати певну зміну суті й значення деяких базових понять, зокрема, еволюцію змісту й розгалуження форм відносин союзницького типу, послаблення артикуляції та скорочення ролі стратегічних партнерств, звуження дистанції між поняттями миру, перемир'я та війни. Цілком звичним явищем стало формування різноманітних ситуативних коаліцій по інтересах та проведення нарад і переговорів зацікавлених сторін попри гострі суперечності між їхніми учасниками 3 низки інших питань. Тимчасові домовленості з окремих аспектів або приватні зобов'язання укладаються частіше, ніж письмові угоди. У багатьох випадках узгодження регуляторних практик оминає їх оформлення як юридичних зобов'язань, що має забезпечувати більшу гнучкість або дозволяти обходити внутрішньополітичні перепони. Приміром, рішення групи G20 (як, до речі, i G7), не створюють юридичних зобов'язань, а їх дотримання відслідковується винятково у формі процесу взаємної оцінки, що має суто консультативний статус. 
Добровільні нормативні обмеження, які не фіксуються в міжнародно-правових актах, усе частіше застосовуються як з боку держав, так i в практиці недержавних акторів. Водночас спостерігається скасування низки формальних міжнародних договорів, зокрема в галузі контролю над озброєннями.

Міждержавні відносини у сфері безпеки створюють основний блок викликів міжнародному порядку. У цьому контексті принципове значення має оцінка загроз політичного, економічного і безпекового характеру, кількість яких збільшується залежно від розвитку новітніх технологій, скорочення життєво важливих ресурсів та перебігу суперництва між провідними у військовому та технологічному відношенні країнами. Загальна тенденція засвідчує зростання ролі силових факторів, які підкреслюють вразливість слабких держав, заохочують центри сили до маніпулювання існуючими міжнародними інституціями та порушення норм формальних (юридично обов'язкових) і неформальних угод і зобов'язань. Ураховуючи сучасну розстановку сил, будь-який спосіб керованості в міжнародній системі може бути реалізований лише за умов досягнення мінімальної згоди між провідними центрами сили. Утім, на практиці така оцінка механізмів глобального регулювання має надто мало спільного з принципами ліберального міжнародного порядку, який декларує відповідність спільним інтересам учасників системи, які дотримуються узгоджених норм поведінки. У порівнянні з переліком традиційних небезпек, у перспективі саме загострення глобальних проблем i спричинених ними міждержавних протиріч становитиме найсерйозніший виклик міжнародному порядку на глобальному та регіональних рівнях, провокуючи порушення звичних норм міжнародної взаємодії та відмову від раціонального самообмеження у поведінці державних суб'єктів.

\section{АНОТАЦІЯ}

3 початку 1990-х рр. в політичному дискурсі спостерігалося широке застосування понять «нового», або «ліберального» міжнародного порядку. У змістовному відношенні вони відображали глобальне розширення структурних елементів міжнародних відносин, опанованих західними ліберальними демократіями в період після Другої світової війни. Західні політичні словники визначають новий міжнародний порядок як стан чи політичну ситуацію, за якої країни світу більше не були змушені розподілятися за критеріями підтримки 
США або СРСР й набули здатності працювати разом із метою вирішення міжнародних проблем.

Найважливішими характеристиками нового, «ліберального» типу міжнародної взаємодії вважалися узгоджений підхід до проблем міжнародної торгівлі, безпеки, прав людини та інших принципових питань світової політики. Утім, консенсус із приводу цих критеріїв і правил виявився нетривким. Після фінансово-економічної кризи 20082009 рр. поточні зміни в балансі сил і впливів суттєво позначилися на сприйнятті загальних норм, які чим далі частіше ставали предметом суперечок між провідними центрами сили.

Дискусія в політико-академічному середовищі щодо перспектив збереження або реформування ліберального порядку зосереджена навколо декількох головних питань. Йдеться насамперед про перспективи дотримання принципів раціональності, нормативності, універсальності та відкритості в регулюванні міжнародних відносин. Натомість зміни, які позначають подалышу корекцію міжнародного порядку, зумовлені загостренням конкуренції та суперництва між великими державами, що супроводжується спробами перегляду взаємоприйнятних форм міждержавної взаємодії. Провідну роль у загостренні конкуренції між провідними державами відіграють зрушення в балансі сил та зростання розбіжностей у підходах політичних кіл США, Росії та Китаю до перспектив глобального розвитку, які суттєво впливають на характер міжнародних відносин і позначаються на ступені визнання усталених принципів і норм багатосторонньої взаємодії на міжнародній арені.

\section{ЛІТЕРАТУРА}

1. Acharya A. After Liberal Hegemony: The Advent of a Multiplex World Order. Ethics \& International Affairs. Fall 2017. Vol. 31. № 3. P. 271-285. DOI: 10.1017/S089267941700020X

2. Allison G. The Myth of the Liberal Order: From Historical Accident to Conventional Wisdom. Foreign Affairs. 2018. July / August. Vol. 97. № 4. P. 124-133.

3. Comstock P. Parag Khanna Discusses The Second World. California Literary Review. 2008. March 4th. URL: http://calitreview.com/396

4. Daalder I.H., Lindsay J.M. The Committee to Save the World Order. America's Allies Must Step Up as America Steps Down. Foreign Affairs. 2018. November / December. Vol. 97. № 6. P. 72-83.

5. Haass R. How a World Order Ends: And What It Comes in Its Wake? Foreign Affairs. 2019. January / February. Vol. 98. № 1. P. 22-30. 
6. Ikenberry G.J. The end of liberal international order? International Affairs. 2018. Vol. 94. № 1. P. 7-23.

7. Ikenberry G.J. The Myth of Post-Cold War Chaos. Foreign Affairs. 1996. May / June. Vol. 75. № 3. P. 79-91. DOI: 10.2307/20047582

8. Ikenberry G.J. Why the Liberal World Order Will Survive. Ethics and International Affairs. 2018. Vol. 3. № 1. P. 17-29. DOI: 10.1017/S0892679418000072

9. It's not just Trump. Challenges to the liberal international order, according to John Ikenberry. Luiss School of Government. 2017. May 25. URL: http://open.luiss.it/en/2017/05/25/non-solo-trump-le-sfide-allordineinternazionale-liberale-secondo-ikenberry/

10. Khanna P. The Second World. Empires and Influence in the New Global Order. New York : Random House, 2008. 496 p.

11. Krauthammer C. The Unipolar Moment. Foreign Affairs. 1990/1991. Winter. Vol. 70. № 1. P. 23-33.

12. Krauthammer C. The Unipolar Moment Revisited. The National Interest. 2002/2003. Winter. № 70. P. 5-17.

13. Leonard M. What Liberal World Order? The Strategist - The Australian Strategic Policy Institute Blog. 2017. March 3. URL: https://www.aspistrategist.org.au/what-liberal-world-order/

14. Lewis J.A. What role should values play in American strategy? Global Forecast 2017. Washington : CSIS, 2016. P. 93-96.

15. Mearsheimer J.J. Bound to Fail. The Rise and Fall of the Liberal International Order. International Security. Spring 2019. Vol. 43. № 4. P. 7-50. DOI: 10.1162/isec_a_00342

16. Nye J.S. Will the Liberal Order Survive? The History of an Idea. Foreign Affairs. 2017. January / February. Vol. 96. № 1. P. 10-16.

17. Posen B.R. The Rise of Illiberal Hegemony: Trump's Surprising Grand Strategy. Foreign Affairs. 2018. March / April. Volume 97. Issue 2. P. 20-27.

18. Wallerstein I. The Three Instances of Hegemony in the History of the Capitalist World-Economy. International Journal of Comparative Sociology. 1983. Vol. XXIV. № 1-2. P. 100-108. DOI: 10.1177/00207 1528302400107

19. Валлерстайн И. Динамика глобального кризиса: тридцать лет спустя. Эксперт. 2009. № 35. С. 48-56.

20. Валлерстайн И. Мир, стабильность и легитимность, 19902025/2050. Анализ мировых систем и ситуаџия в современном мире ; пер. П.М. Кудюкина. Москва : Изд-во «Университетская книга», 2001. C. $347-370$. 
21. Киссинджер Г. Дипломатия ; пер. В.В. Львова. Москва : Ладомир, 1997. 848 с.

22. Киссинджер Г. Мировой порядок ; пер. В. Желнинова, А. Милюкова. Москва : Изд-во АСТ, 2018. 512 с.

23. Кортунов А. Неизбежность странного мира. РСМД. 2016. 15 июля. URL: http://old.russiancouncil.ru/inner/?id_4=7930\#top-content

\section{Information about author:} Tolstov S. V.,

Candidate of Historical Sciences, Head of the Department of Transatlantic Studies Institute of World History of the National Academy of Sciences of Ukraine 5, Leontovicha str., Kyiv, Ukraine 